\title{
Antimicrobial activity and safety evaluation of Enterococcus faecium KQ 2.6 isolated from peacock feces
}

Wei Zheng ${ }^{1}$, Yu Zhang ${ }^{1}$, Hui-Min Lu', Dan-Ting Li ${ }^{1}$, Zhi-Liang Zhang ${ }^{1}$, Zhen-Xing Tang ${ }^{2}$ and Lu-E Shi ${ }^{1 *}$

\begin{abstract}
Background: The objective of this paper was to study antimicrobial activity and safety of Enterococcus faecium KQ 2.6 (E. faecium KQ 2.6) isolated from peacock feces.

Methods: Agar well diffusion method was adopted in antimicrobial activity assay. Disk diffusion test was used to determine the antibiotic resistance. The identification and virulence potential of E. faecium KQ 2.6 were investigated using PCR amplification.

Results: The results indicated that cell free supernatant (CFS) of the strain had the good antimicrobial activity against selected gram-positive and gram-negative bacteria. The biochemical characteristics of antimicrobial substances were investigated. The results indicated that the antimicrobial substances were still active after treatment with catalase and proteinase, respectively. Moreover, the stability of antimicrobial substances did not change after heat treatment at 40, $50,60,70$ and $80^{\circ} \mathrm{C}$ for $30 \mathrm{~min}$, respectively. The activity of antimicrobial substances remained stable at 4 and $-20^{\circ} \mathrm{C}$ after long time storage. The antimicrobial activity of CFS was compared with that of the buffer with similar strength and $\mathrm{pH}$. The inhibitory zone of the buffer was apparently smaller than that of CFS, which meant that the acid in CFS was not the only factor that was contributed to antibacterial activity of CFS. The antibiotic resistance and virulence potential were evaluated using disk diffusion test and PCR amplification. The results showed that E. faecium KQ 2.6 did not harbor any tested virulence genes such as gelE, esp, asa1, cylA, efaA and hyl. It was susceptible to most of tested antibiotics except for vancomycin and polymyxin $B$.
\end{abstract}

Conclusion: E. faecium KQ 2.6 may be used as bio-preservative cultures for the production of fermented foods.

Keywords: E. faecium KQ 2.6, Antimicrobial activity, Safety evaluation, Antibiotics resistance, Virulence genes

\section{Background}

Enterococci belong to lactic acid bacteria (LAB), which are widespread in foods and environment. In aspect of food fermentation, it is considered that enterococci play an important role in the development of the sensory characteristics of fermentation foods such as sausages and cheeses [1]. Certain cheese-makers have suggested that enterococci can be utilized as starter cultures in the production of Mediterranean cheese [2,3]. Furthermore, some enterococcal strains have been successfully used as preservatives to inhibit the growth of food spoilage

\footnotetext{
*Correspondence: shilue@126.com

${ }^{1}$ College of Life and Environmental Sciences, Hangzhou Normal University,

310016 Hangzhou, Zhejiang, China

Full list of author information is available at the end of the article
}

microorganisms. One of reasons that these enterococcal strains with antimicrobial activity, produce lactic acid [4]. Lactic acid reduces the $\mathrm{pH}$ that can cause the disruption of cellular substrate transport systems through altering the cell membrane permeability or collapsing the electrochemical proton gradient [5]. In addition, enterococci also can produce other antimicrobial substances such as hydrogen peroxide, bacteriocin and bacteriocin like inhibitory substances (BLIS). In past few years, bacteriocin has been increasingly concerned due to its diversity and novelty. Bacteriocins are ribosomally synthesized, extracellularly released low-molecular-mass peptides or proteins [6,7]. Generally, most known bacteriocins produced by E. faecium, are small $(<10 \mathrm{kDa})$, membrane-active and unmodified peptides. One of the 
most obvious traits of these bacteriocins is sensitive to proteolytic enzymes. For example, enterocin A and enterocin B from E. faecium MMT21 are both sensitive to trypsin, proteinase $\mathrm{K}$ and pronase $\mathrm{E}$ [8-11].

Enterococci have been used safely in foods for a long history. However, in past few years, the concerns on the safety of enterococci in food or feed industries have been raised. Many studies have reported that enterococci are associated with nosocomial infections like bacteraemia, endocarditis, urinary tract infections and diarrhea $[12,13]$. The main reasons that cause nosocomial infections, are the resistance of the strains to a board range of antibiotics and the presence of virulence factors in the strains [14]. The multiple antibiotic resistant strains often cause serious infections which can't be cured well. In particular, vancomycin-resistant enterococci (VRE) have produced serious problems in public health [15]. Virulence factors have been well studied in recent years, and some virulence factors have been reported in detail. The main described factors are those are involved in adhesion, damaging tissues and evasion of immune responses (capsular polysaccharides) [16]. Additionally, it should be mentioned that enterococci may acquire antibiotic resistance and virulence factors from other enterococci, since mobile genetic elements like plasmids and transposons, can contribute to the distribution of antibiotic resistance and virulence factors between enterococcal strains $[17,18]$. Therefore, the safety evaluation of the enterococci should be carried out before the application.

In present study, one enterococcal strain isolated from peacock feces was identified as E. faecium KQ 2.6 by PCR and 16S rRNA gene sequencing. Antimicrobial activity and safety of this strain was mainly studied. The production and biochemical properties of antimicrobial substances were also investigated.

\section{Methods}

All chemicals were purchased from Sangon (Shanghai, China). Indicator strains and antibiotic-containing disks were obtained from Binhe Microorganism Reagent Co. Ltd (Hangzhou, China). Participants in the study agreed to carry out the following studies. No human subjects including human material or human data, were contained in present study.

\section{Bacterial isolation and identification}

Peacock feces were collected in an animal centre located in Hangzhou Normal University. Ten-fold dilutions of feces in sterile water were plated onto de Man, Rogosa and Sharpe (MRS). The plates were incubated at $37^{\circ} \mathrm{C}$ for $24 \mathrm{~h}$. Twelve of colonies were randomly picked and used for the study of physiological and biochemical characteristics. Meanwhile, the antimicrobial activity of the strains against Escherichia Coli was studied using the agar spot method [19]. The strains displaying an inhibition zone were selected, and maintained as stock cultures in MRS broth supplemented with $30 \%(\mathrm{v} / \mathrm{v})$ glycerol at $-20^{\circ} \mathrm{C}$.

Primers, 27 F (5'-AGAGTTGATCCTGGCTCAG-3') and 1492R (5' - GGTTACCTTGTTACGACTT-3') based on conserved regions of 16SrRNA gene were used to direct the amplification. The program consisted of: denaturation at $94^{\circ} \mathrm{C}$ for $5 \mathrm{~min}$, then 35 cycles of $94^{\circ} \mathrm{C}$ for $1 \mathrm{~min}, 55^{\circ} \mathrm{C}$ for $1 \mathrm{~min}$ and $72^{\circ} \mathrm{C}$ for $1 \mathrm{~min}$ followed by a final extension at $72^{\circ} \mathrm{C}$ for $5 \mathrm{~min}$. Amplified PCR products were separated by $1.0 \%(\mathrm{w} / \mathrm{v})$ agarose gel electrophoresis, and then purified with the StarPrep Gel Extraction Kit (GenStar, Beijing, China) according to manufacturer's instruction. 16S rRNA gene sequencing was carried out by Sunny Biotechnology Co., Ltd (Shanghai, China).

\section{Antimicrobial activity assay of E. faecium KQ 2.6}

The antimicrobial activity of E. faecium KQ 2.6 against pathogenic bacteria was investigated. Pathogenic bacteria included Bacillus subtilis, Bacillus cereus, Streptococcus pyogenes, Staphylococcus aureus, Staphylococcus epidermidis, E. faecalis, Escherichia coli, Pseudomonas aeruginosa, Klebsiella pneumoniae, Salmonella paratyphi, Candida albicans and Aspergillus niger. The antimicrobial assay was performed using agar well diffusion method [20]. Firstly, E. faecium KQ 2.6 was grown overnight in MRS broth at $37^{\circ} \mathrm{C}$. Cells in the culture were discarded by centrifugation at $10,000 \mathrm{~g}$ at $4^{\circ} \mathrm{Cfor}$ $20 \mathrm{~min} .60 \mu \mathrm{L}$ of indicator bacteria (final concentration of $10^{8} \mathrm{CFU} / \mathrm{mL}$ ) cultured in $20 \mathrm{~mL}$ soft agar containing $0.80 \%(w / v)$ agar was poured onto a solid agar plate containing $1.5 \%(\mathrm{w} / \mathrm{v})$ agar. Afterwards, wells $(8 \mathrm{~mm}$ in diameter) were made on agar plate, and filled with $100 \mu \mathrm{L}$ of cell free supernatant (CFS) of E. faecium KQ 2.6. Plates were incubated at $37^{\circ} \mathrm{C}$ for $24 \mathrm{~h}$ after being kept for $3-4 \mathrm{~h}$ at $4^{\circ} \mathrm{C}$. Finally, the antimicrobial activity was analyzed by observing the clear zones around the wells containing CFS. The clear zones were regarded as inhibitory zones, and recorded in $\mathrm{mm}$.

\section{Growth kinetics and antimicrobial activity of $E$. faecium KQ 2.6}

$100 \mathrm{~mL}$ of MRS broth was inoculated with $1.0 \%(\mathrm{v} / \mathrm{v})$ of the culture of E. faecium KQ 2.6 and incubated at $37^{\circ} \mathrm{C}$. Optical density at $600 \mathrm{~nm}\left(\mathrm{OD}_{600}\right)$ and $\mathrm{pH}$ values were monitored at $2 \mathrm{~h}$ intervals during $24 \mathrm{~h}$. The antimicrobial activity assay was also performed every two hours. To quantify the antimicrobial activity, CFS was serially diluted 2-folds and $10 \mu \mathrm{L}$ of each dilution was added into the wells. The titer was defined as $2^{\mathrm{n}}$, which is the reciprocal of the highest dilution showing inhibition of 
indicator strain. Thus, the arbitrary unit (AU) of antimicrobial activity per milliliter was defined as $2^{\mathrm{n}} \times(1,000 \mu \mathrm{L} / 10 \mu \mathrm{L})[21]$.

Effect of the biochemical factors on antimicrobial activity E. faecium KQ 2.6 was cultivated in MRS broth at $37^{\circ} \mathrm{C}$ for $16 \mathrm{~h}$. CFS was obtained by centrifugation at $10,000 \mathrm{~g}$ at $4^{\circ} \mathrm{C}$ for $20 \mathrm{~min}$, and used to carry out the following studies.

Antimicrobial activity of CFS at different temperatures was investigated. CFS was treated at $40,50,60,70$ and $80^{\circ} \mathrm{C}$ for $30 \mathrm{~min}$ and $3 \mathrm{~h}$, respectively, and at $121^{\circ} \mathrm{C}$ for $20 \mathrm{~min}$. Storage stability of CFS at 4 and $-20^{\circ} \mathrm{C}$ for 24 , 48 h, 7 days and 15 days, was also performed.

The sensitivity of antimicrobial substances towards catalase and proteinase was studied. $1.0 \mathrm{~mL}$ of CFS was added to $1.0 \mathrm{~mL}$ of $1.0 \mathrm{mg} / \mathrm{mL}$ catalase, trypsin and pepsin, respectively. Afterwards, samples were incubated at $37^{\circ} \mathrm{C}$ for $30 \mathrm{~min}$, and heated at $95^{\circ} \mathrm{C}$ for $5 \mathrm{~min}$.

All treated samples were tested against Bacillus cereus using agar well diffusion method. Each experiment was performed at least two times. In addition, the antimicrobial activity was done using hydrogen phosphate/citric acid buffer which had a similar $\mathrm{pH}$ and strength to CFS of E. faecium KQ 2.6.

\section{Antibiotic resistance}

Disk diffusion test was used to determine the susceptibility of E. faecium KQ 2.6 to antibiotics [22]. Antibioticcontaining disks were those of penicillin, vancomycin, chloramphenicol, tetracycline, erythromycin, rifampicin, ofloxacin, polymyxin B and ciprofloxacin. $20 \mathrm{~mL}$ of MRS broth containing $1.5 \%$ agar was seeded with $200 \mu \mathrm{L}$ of a culture of E. faecium KQ $2.6\left(10^{6}-10^{7} \mathrm{CFU} / \mathrm{mL}\right)$, and poured into a plate. Then antibiotic-containing disks were added onto the plates according to the manufacturer's instructions. Inhibition zone diameters with/without vancomycin-containing disks were measured $(\mathrm{mm})$ at $37^{\circ} \mathrm{C}$ after 24 and $18 \mathrm{~h}$ incubation, respectively. According to the recommendation of Clinical and Laboratory Standards Institute (CLSI), the strain was considered to be resistant to antibiotics if the inhibition zone was equal or smaller than $16 \mathrm{~mm}$ for rifampicin, $15 \mathrm{~mm}$ for ciprofloxacin, $14 \mathrm{~mm}$ for penicillin, vancomycin and tetracycline, $13 \mathrm{~mm}$ for erythromycin and ofloxacin, and $12 \mathrm{~mm}$ for chloramphenicol.

\section{PCR for the detection of virulence genes}

PCR amplification was used to detect virulence genes gelE (gelatinase), esp (enterococcal surface protein), asa1 (aggregation substance), cylA (cytolysin), efaA (cell-wall adhesion) and $h y l$ (hyaluronidase). Primers are listed in Table 1. The following PCR conditions were used: $94^{\circ} \mathrm{C}$ for $5 \mathrm{~min}$; followed by 35 cycles of $94^{\circ} \mathrm{C}$ for $1 \mathrm{~min}, 52^{\circ} \mathrm{C}$
Table 1 Primer pairs used for detection of virulence genes

\begin{tabular}{llll}
\hline Gene & Primers $\mathbf{( 5}^{\prime}$-3') & Size (bp) & References \\
\hline gelE & F: TATGACAATGCTTITGGGAT & 213 & {$[37]$} \\
& R: AGATGCACCCGAAATAATATA & & \\
esp & F: AGATTTCATCTITGATTCTTG & 510 & {$[37]$} \\
& R: AATTGATTCTTIAGCATCTGG & & \\
asal & F: GCACGCTATTACGAACTATGA & 375 & {$[37]$} \\
& R: AAGAAAGAACATCACCACGA & & \\
cylA & F: ACTCGGGGATTGATAGGC & 688 & {$[37]$} \\
& R: GCTGCTAAAGCTGCGCT & & \\
efaA & F: GACAGACCCTCACGAATA & 705 & {$[18]$} \\
& R: AGTTCATCATGCTGTAGTA & & \\
hyl & F: ACAGAAGAGCTGCAGGAAATG & 276 & {$[37]$} \\
& R: GACTGACGTCCAAGTTCCAA & & \\
\hline
\end{tabular}

(for gelE, efaA), $56^{\circ} \mathrm{C}$ (for cylA, asa1, esp) and $58^{\circ} \mathrm{C}$ (for $h y l)$ for $30 \mathrm{~s}, 72^{\circ} \mathrm{C}$ for $1 \mathrm{~min}$; a final extension at $72^{\circ} \mathrm{C}$ for $5 \mathrm{~min}$. The DNA from $E$ faecalis ATCC 29212 (asa1 ${ }^{+}$, $c y l A^{+}, \mathrm{gelE}^{+}, e f a A^{+}$and $h y l^{+}$) was used as a positive control. The amplified products were analyzed by electrophoresis on $1.0 \%(\mathrm{w} / \mathrm{v})$ agarose gels in $1 \times$ TAE buffer.

\section{Results}

Isolation and identification of LAB strains with antimicrobial activity

Antimicrobial activity of twelve strains isolated from peacock feces, were studied using the agar spot method. The results indicated that only two isolates had obvious antimicrobial activity against Escherichia coli (data not shown). According to the studies of physiological and biochemical characteristics, one of two isolates could produce gas through glucose fermentation. It was not convenient to control the fermentation process easily. Therefore, the strain with good antimicrobial activity and gas-negative property, was chosen for this study. The sequencing of the partial $16 \mathrm{~S}$ rRNA of the strain showed 99 \% homology to that of E. faecium 3-2-31, so it was identified as E. faecium KQ 2.6.

\section{Spectrum of antimicrobial activity}

As shown in Figure 1, CFS of E. faecium KQ 2.6 could exert inhibiting activity to the growth of Bacillus subtilis, Bacillus cereus and Escherichia coli. The growth of a panel of pathogenic gram-positive and gram-negative bacteria including Bacillus subtilis, Bacillus cereus, Streptococcus pyogenes, Staphylococcus epidermidis, Pseudomonas aeruginosa, Salmonella paratyphi and E. faecalis, was also inhibited by CFS of E. faecium KQ 2.6. However, it was not active against fungi like Candida albicans and Aspergillsu niger (Table 2). 

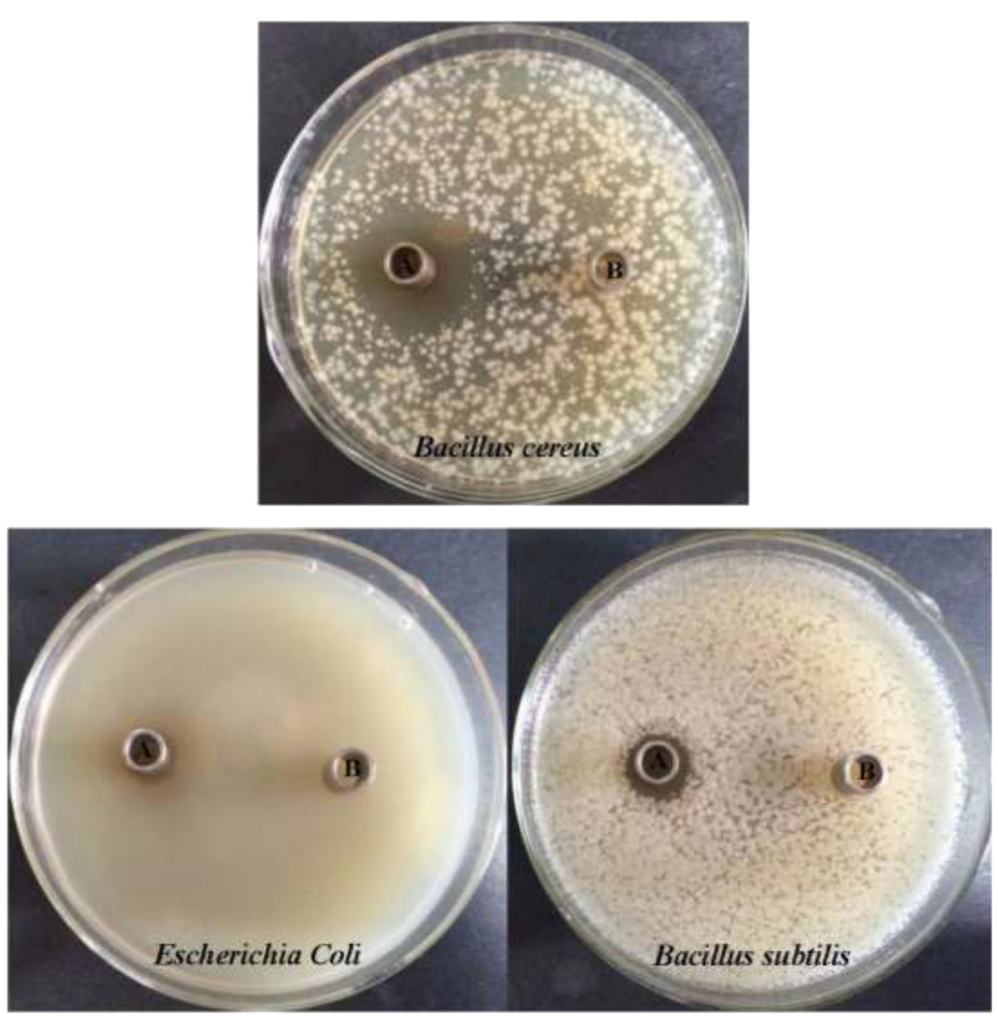

Figure 1 Antimicrobial activity of CFS against Bacillus cereus, Escherichia coli and Bacillus subtilis. A: CFS of E. faecium KQ 2.6, B: Luria-Bertani broth.

Table 2 Antimicrobial activity of CFS produced by $E$. faecium KQ 2.6

\begin{tabular}{|c|c|c|c|}
\hline Indicator strains & Medium & $\begin{array}{l}\text { Incubation } \\
\text { temperature }\left({ }^{\circ} \mathrm{C}\right)\end{array}$ & $\begin{array}{l}\text { Antimicrobial } \\
\text { activity }^{\text {a }}\end{array}$ \\
\hline \multicolumn{4}{|l|}{ Gram-positive } \\
\hline Bacillus subtilis & LB & 37 & + \\
\hline Bacillus cereus & LB & 37 & +++ \\
\hline Streptococcus pyogenes & LB & 37 & ++ \\
\hline Staphylococcus aureus & LB & 37 & - \\
\hline Staphylococcus epidermidis & LB & 37 & ++ \\
\hline E. faecalis & MRS & 37 & + \\
\hline \multicolumn{4}{|l|}{ Gram-negative } \\
\hline Escherichia Coli & LB & 37 & + \\
\hline Pseudomonas aeruginosa & LB & 37 & ++ \\
\hline Klebsiella pneumoniae & LB & 37 & - \\
\hline Salmonella paratyphi & LB & 37 & +++ \\
\hline \multicolumn{4}{|l|}{ Fungi } \\
\hline Candida albicans & PDA & 28 & - \\
\hline Aspergillus niger & PDA & 28 & - \\
\hline
\end{tabular}

${ }^{a}$ Results of antimicrobial activity were recorded in the diameter of inhibition zones around the wells ( $8 \mathrm{~mm}$ in diameter): - , no inhibition zone; + , zone $<5 \mathrm{~mm}$; ++, zone $<5-10 \mathrm{~mm} ;+++$, zone $>15 \mathrm{~mm}$.

\section{Production of antimicrobial substances and growth kinetics}

The results of the cell density, $\mathrm{pH}$ of the media and production of antimicrobial substances were obtained during $24 \mathrm{~h}$ of growth at $37^{\circ} \mathrm{C}$ (Figure 2). During this period, the cell density of E. faecium KQ 2.6 increased from 0.03 to $1.37\left(\mathrm{OD}_{600}\right) \cdot \mathrm{pH}$ of the media dropped down to 4.5. E. faecium KQ 2.6 began to produce antimicrobial substances (200 AU/mL) after $4 \mathrm{~h}$ of growth. Maximum values (1600 AU/mL) of antimicrobial activity was reached at the early stationary phase $(16 \mathrm{~h})$, and remained un-change in the following $8 \mathrm{~h}$ of growth.

\section{Characterization of antimicrobial substances}

Except for heat treatment at $121^{\circ} \mathrm{C}$ for $20 \mathrm{~min}$, the substances remained stable after heating at 40, 50, 60, 70 and $80^{\circ} \mathrm{C}$ for $30 \mathrm{~min}$, respectively. Meanwhile, antimicrobial activity did not change when CFS was stored at low temperatures $\left(4\right.$ and $\left.-20^{\circ} \mathrm{C}\right)$ for $24,48 \mathrm{~h}, 7$ and 15 days (Table 3). It showed that storage conditions did not led to the decrease of antimicrobial activity significantly. Additionally, the addition of catalase, trypsin and pepsin to CFS had no effect on antimicrobial activity of CFS (Table 3). The inhibitory zone of hydrogen phosphate/ 


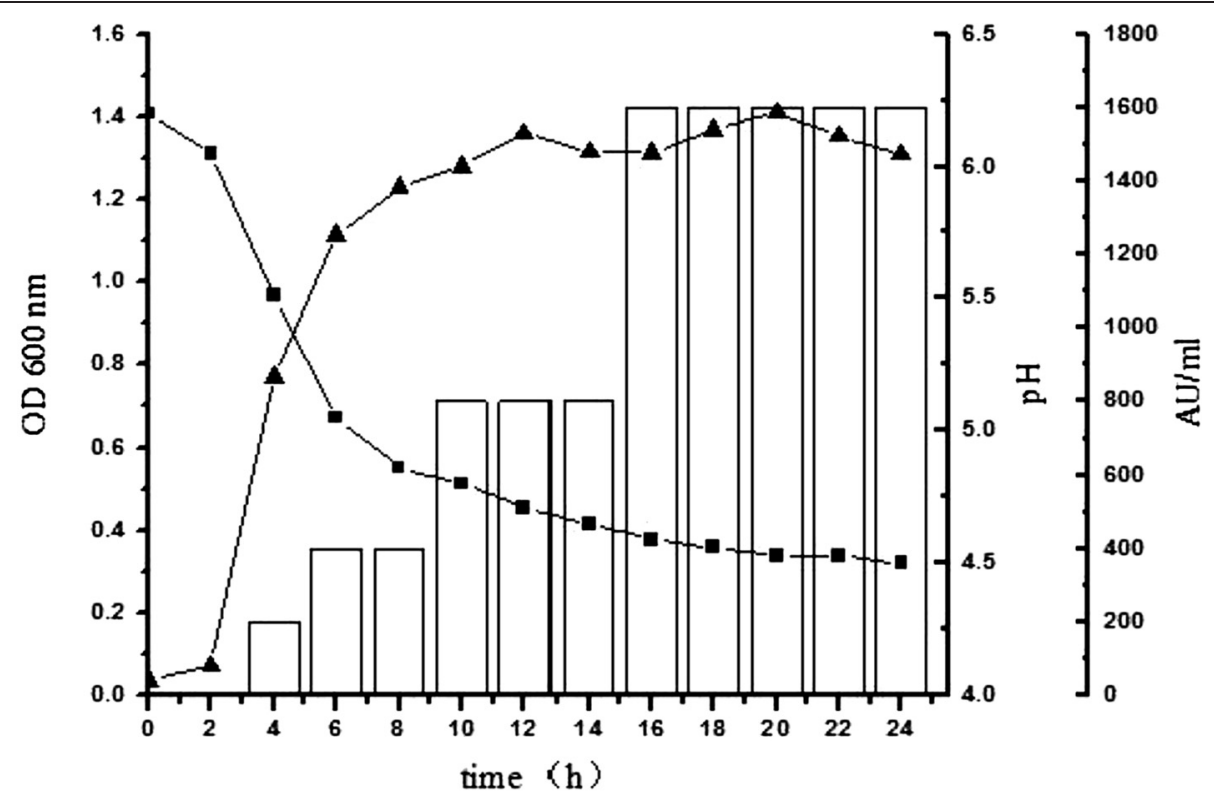

Figure 2 Kinetics growth curves and production of antimicrobial substances by E. faecium KQ 2.6. $\mathbf{\Delta}: \mathrm{OD}_{600}$; $\mathbf{m}$ pH of the culture medium; black histograms: antimicrobial activity against Bacillus cereus.

citric acid buffer was apparently smaller than that of CFS (Figure 3).

\section{Detection of antibiotic resistance and potential virulence factors}

Phenotypic results from disk diffusion test demonstrated that E. faecium KQ 2.6 was highly susceptible to most of tested antibiotics such as penicillin, chloramphenicol, tetracycline, erythromycin, rifampicin, ofloxacin and ciprofloxacin. However, it was also found that the strain was resistant to vancomycin and polymyxin B (Table 4).

Table 3 Effect of temperature and enzymes on the activity of CFS of E. faecium KQ 2.6

\begin{tabular}{ll}
\hline Treatments & Antimicrobial activity $^{\mathbf{a}}$ \\
\hline Temperature & + \\
$40^{\circ} \mathrm{C}$ for $30 \mathrm{~min}$ & + \\
$50^{\circ} \mathrm{C}$ for $30 \mathrm{~min}$ & + \\
$60^{\circ} \mathrm{C}$ for $30 \mathrm{~min}$ & + \\
$70^{\circ} \mathrm{C}$ for $30 \mathrm{~min}$ & + \\
$80^{\circ} \mathrm{C}$ for $30 \mathrm{~min}$ & - \\
$121^{\circ} \mathrm{C}$ for $20 \mathrm{~min}$ & \\
Enzymes & + \\
Catalase & + \\
Trypsin & + \\
Pepsin & + \\
\hline
\end{tabular}

$a_{+}$, presence of antimicrobial activity; ${ }_{-}$, absence of antimicrobial activity; the indicator strain, Bacillus cereus
Whether the presence of virulence genes encoding gelE, esp, asa1, cylA, efaA and $h y l$ in the strain was investigated. The results from agarose gel electrophoresis showed that E. faecium KQ 2.6 did not harbor virulence genes including gelE (213 bp), esp (511 bp), asa1 (328 bp), cylA (688 bp), efaA (704 bp) and hyl (276 bp) (Figure 4).

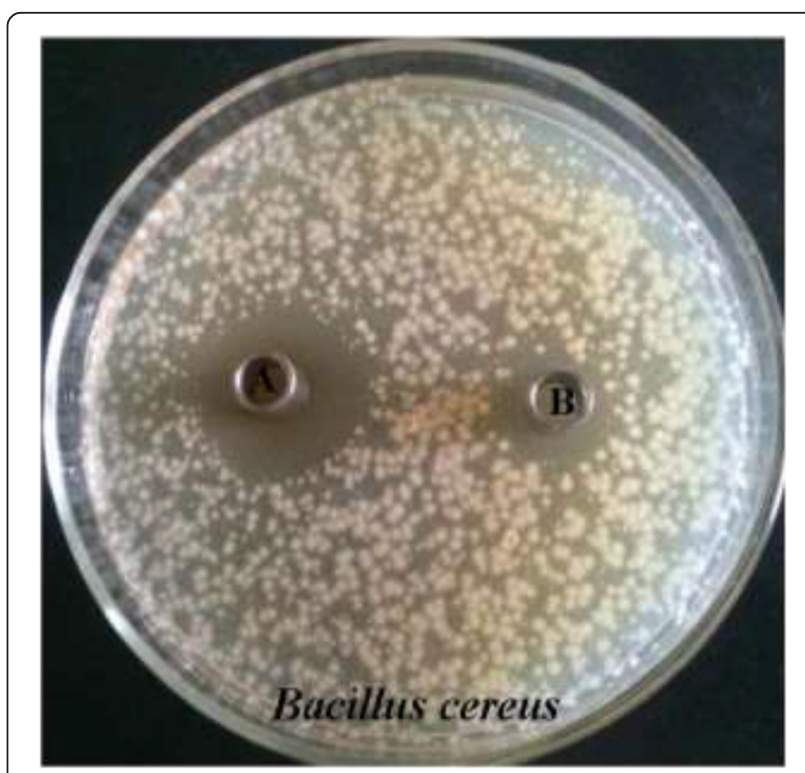

Figure 3 Antimicrobial activity of CFS and buffer against Bacillus cereus. A: CFS of E.faecium KQ 2.6, B: hydrogen phosphate/citric acid buffer. 
Table 4 Antibiotic resistant profile of E. faecium KQ 2.6

\begin{tabular}{lll}
\hline Antibiotics & Drug concentration per disk $(\boldsymbol{\mu g})$ & Susceptibility $^{\mathbf{a}}$ \\
\hline Penicillin & 10 & $\mathrm{~S}$ \\
Vancomycin & 30 & $\mathrm{R}$ \\
Chloramphenicol & 30 & $\mathrm{~S}$ \\
Tetracycline & 30 & $\mathrm{~S}$ \\
Ofloxacin & 5 & $\mathrm{~S}$ \\
Erythromycin & 15 & $\mathrm{~S}$ \\
Rifampicin & 5 & $\mathrm{~S}$ \\
Polymyxin B & 30 & $\mathrm{R}$ \\
Ciprofloxacin & 5 & $\mathrm{~S}$ \\
\hline
\end{tabular}

${ }^{a}$ The antibiotic resistance was determined by disk diffusion test. The sensitive was analyzed by the recommendation of CLSI (2008). S: sensitive; R: resistant.

\section{Discussion}

Enterococci occur in many different environments such as in air, soil, water and the gastrointestinal tract of animals and humans. Due to the association of enterococci with the gastrointestinal tract, it is an ordinary and efficient method to screen enterococci from animal feces. In the last decades, the benefic role of enterococci from animal and human feces in food and animal industries has been well studied $[1,23,24]$. In this study, twelve isolates were screened from peacock feces, and two of them displayed good antimicrobial properties. The highest antimicrobial activity and gas-negative strain was named as $E$. faecium KQ 2.6.

Antimicrobial activity of E. faecium KQ 2.6 was evaluated. The results showed that this strain was able to inhibit gram-positive and gram-negative bacteria. It should be pointed out that many enterococci can produce bacteriocins, which exhibit activity towards gram-positive and gram-negative bacteria [25]. Therefore, the hypothesis that antimicrobial activity of E. faecium KQ 2.6 is due to the produced bacteriocin, may be established. However, the activity did not lost after CFS of E. faecium KQ 2.6 was treated by proteinase. It demonstrated that the antimicrobial factors were not protein components such as bacteriocin or BLIS. The resistance of CFS to catalase indicated that antimicrobial substance was not hydrogen peroxide. Regarding this phenomenon, some reports have been indicated that the antimicrobial activity may be due to the produced acid [26,27]. Anyogu et al. [28] also indicated that the acid substances produced by $E$. faecium was an important factor to deter the growth and survival of pathogens in the process of submerged cassava fermentation. Therefore, the antimicrobial activity of enterococci in this study may be due to the production of organic acids. Our results showed that the produced acid was not the only factor that contributed to antimicrobial activity of CFS of E. faecium KQ 2.6, since the inhibitory zone of CFS was significantly bigger than that of the buffer with similar $\mathrm{pH}$ and strength. Thus, we believed that another type of antimicrobial substance should be in CFS of E. faecium KQ 2.6.

To study antimicrobial substances of E. faecium KQ 2.6 more specially, the heat stability and storability were investigated. The activity could be kept stably after a long time storage or high temperature treatment. It indicated that storage conditions did not lead to the decrease of antimicrobial activity significantly. The high stability of antimicrobial activity can be a good criterion

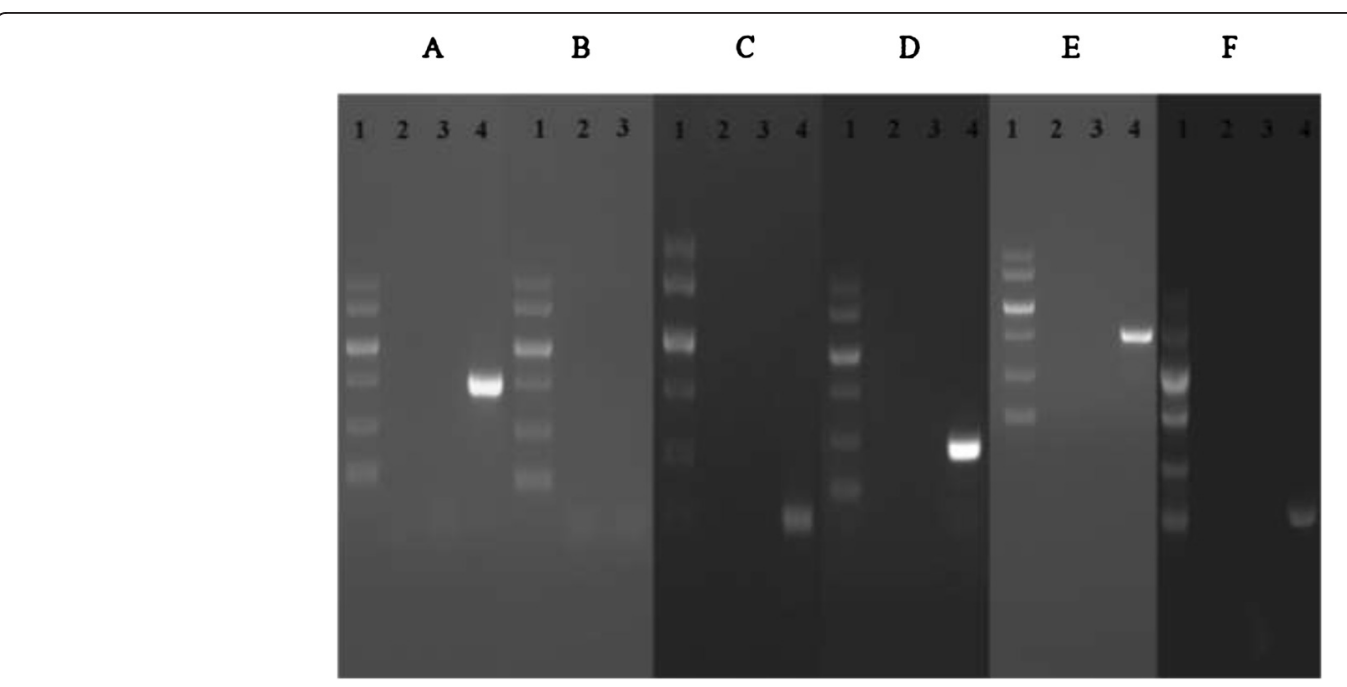

Figure 4 Results of E. faecium KQ 2.6 using primers directed against (A) 688 bp fragment of the cylA gene, (B) 510 bp fragment of the esp gene, (C) $213 \mathrm{bp}$ fragment of the gelE gene, (D) $375 \mathrm{bp}$ fragment of the asal gene, (E) $705 \mathrm{bp}$ fragment of the efaA gene and (F) $276 \mathrm{bp}$ fragment of the hyl gene. Lane 1: standard molecular weight (2000 kb); lane 2: negative control; lane 3: E. faecium KQ 2.6; lane 4: positive control (E. faecalis ATCC 29212). 
for its use as a bio-preservative under complicated conditions of food processing.

The incidence of antibiotic resistance has been received high attention as it is of vital point for the safe use of the strains in foods. It is clear that in hospital environment, multiple antibiotic resistant strains may lead to infections or super-infections. Enterococci are the fourth prevalent strains causing blood infections in European hospital, and the proportion of enterococcal infections continues to increase, mainly because of an increasing number of antibiotic resistant E. faecium [29]. In our study, E. faecium KQ 2.6 had resistance to vancomycin and polymyxin $\mathrm{B}$. The results indirectly agreed with the study of Messi et al. [30]. Vancomycin-resistance enterococci (VRE) are not restricted to clinical strains, but can be obtained from animal organs and environment. In last few years, the numbers of VRE have been increasing [31]. VRE have brought treatment difficulty, as vancomycin is the last few therapeutic options for enterococcal infections $[32,33]$. The mechanism of the high resistance to vancomycin is the replacement of the terminal D-Ala of peptidoglycan precursors with D-lactate, which can prevent or destroy the combination between vancomycin and peptidoglycan precursors [34]. Fortunately, E. faecium KQ 2.6 was sensitive to the most common antibiotics such as penicillin, tetracycline, chloramphenicol and ciprofloxacin. Therefore, the strain was not multiple antibiotic resistant enterococci.

The investigation of antibiotic resistance alone can't evaluate the safety of enterococci completely. Virulence factors are greatly contributed to enhance infection risks, so potential virulence genes of E. faecium KQ 2.6 need to be evaluated. It was reported that the genes encoding adhesion-associated protein were rarely detected in $E$. faecium strain from foods [18]. The absence of full $C y l$ operon in E. faecium has also been reported [31]. Our results indicated that this strain did not harbor tested virulence genes gelE, esp, asa1, cylA, efaA and $h y l$, which was in agreement with the above conclusions. In general, the clinical enterococci harbor more virulence factors than E. faecium KQ 2.6.

However, it should be noted that mobile genetic elements like plasmids and transposons, may contribute to the distribution of virulence factors between enterococcci isolated from different sources $[17,18]$. The virulence genes acquisitions in E. faecium have been reported. Clonal complex 17 lineage, a kind of E. faecium genetic lineage, can obtain an esp gene from other clinical enterococci. And this lineage not only occurs in hospital but also is found in foods $[35,36]$. Another study indicated that less than $40 \%$ of E. faecalis proteins have been found in $E$. faecium draft genome. So, E. faecium may harbor additional virulence factors from E. faecalis [16]. Furthermore, Sex pheromones or gene transfer pheromones may promote acquisition of virulence genes from other enterococci. Even it is not a common trait that enterococci produce sex pheromones or gene transfer pheromones [18], the work on detecting the presence of sex pheromones or gene transfer pheromones will contribute to assess the safety of the strain.

\section{Conclusion}

To our knowledge, this is the first report on the study of E. faecium isolated from peacock feces. E. faecium $\mathrm{KQ}$ 2.6 not only inhibited the growth of gram-positive bacteria, but also had antimicrobial activity towards gramnegative bacteria. The antimicrobial substance was not hydrogen peroxide or protein components. Part inhibitory effect of E. faecium KQ 2.6 might be due to the produced acid. Another antimicrobial substance should be in CFS of E. faecium KQ 2.6. E. faecium KQ 2.6 may be considered safely for its susceptibility to most common antibiotics and absence of the most studied virulence genes. Therefore, this strain has potential to be used as a food preservative in our daily life. However, it should be further evaluated for its ability of virulence genes acquisitions before this strain is applied in the food and/or feed industries.

\section{Abbreviation \\ E. faecium KQ 2.6: Enterococcus faecium KQ 2.6; E. faecalis: Enterococci faecalis; CFS: Cell free supernatant; BLIS: Bacteriocin like inhibitory substances; LAB: Lactic acid bacteria; VRE: Vancomycin-resistant enterococci; LB: Luria-Bertani broth; MRS: de Man Rogosa Sharpe agar; PDA: Potato Dextrose Agar; CLSI: Clinical and Laboratory Standards Institute.}

\section{Competing interests}

The authors declare that they have no competing interests.

\section{Authors' contributions}

LES participated in the design of the study, carried out the experiments, analyzed the results. WZ participated in the experiments and wrote the manuscript. The rest authors participated in analyzing the results and corrected the manuscript. All authors read and approved the final manuscript.

\section{Acknowledgements}

This study was financially supported by the Xinmiao Talent Program of Zhejiang Province (2012R421003, 2013R421006).

\section{Author details}

${ }^{1}$ College of Life and Environmental Sciences, Hangzhou Normal University, 310016 Hangzhou, Zhejiang, China. ${ }^{2}$ College of Light Industry Science and Engineering, Nanjing Forestry University, 210037 Nanjing, Jiangsu, China.

Received: 1 January 2015 Accepted: 22 April 2015

Published online: 12 May 2015

\section{References}

1. Sánchez J, Basanta A, Gómez-Sala B, Herranz C, Cintas LM, Hernández PE. Antimicrobial and safety aspects, and biotechnological potential of bacteriocinogenic enterococci isolated from mallard ducks (Anas platyrhynchos). Int J Food Microbiol. 2007;117:295-305.

2. Centeno JA, Menéndez S, Rodríguez-Otero JL. Main microbial flora present as natural starters in Cebreiro raw cow's-milk cheese (Northwest Spain). Int J Food Microbiol. 1996;33:307-13.

3. Parente E, Villani F, Coppola R, Coppola S. A multiple strain starter for water-buffalo Mozzarella cheese manufacture. Lait. 1989;69:271-9. 
4. Daeschel MA. Antimicrobial substances from lactic acid bacteria for use as food preservatives. Food Technol. 1989;43:164-7.

5. Ammor S, Tauveron G, Dufour E, Chevallier I. Antibacterial activity of lactic acid bacteria against spoilage and pathogenic bacteria isolated from the same meat small-scale facility: 1-Screening and characterization of the antibacterial compounds. Food Control. 2006;17:454-61.

6. Foulquié Moreno M, Callewaert R, Devreese B, Van Beeumen J, De Vuyst L. Isolation and biochemical characterisation of enterocins produced by enterococci from different sources. J Appl Microbiol. 2003;94:214-29.

7. Klaenhammer TR. Bacteriocins of lactic acid bacteria. Biochimie. 1988;70:337-49.

8. Abriouel H, Lucas R, Ben Omar N, Valdivia E, Maqueda M, Martínez-Cañamero $\mathrm{M}$, et al. Enterocin AS-48RJ: a variant of enterocin AS-48 chromosomally encoded by Enterococcus faecium RJ16 isolated from food. Syst Appl Microbiol. 2005;28:383-97.

9. Ghrairi T, Frere J, Berjeaud J, Manai M. Purification and characterisation of bacteriocins produced by Enterococcus faecium from Tunisian rigouta cheese. Food Control. 2008;19:162-9.

10. Gutiérrez J, Criado R, Citti R, Martín M, Herranz C, Nes IF, et al. Cloning, production and functional expression of enterocin $\mathrm{P}$, a sec-dependent bacteriocin produced by Enterococcus faecium P13, in Escherichia coli. Int J Food Microbiol. 2005;103:239-50.

11. Snyder AB, Worobo RW. Chemical and genetic characterization of bacteriocins: antimicrobial peptides for food safety. J Sci Food Agr. 2014;94:28-44

12. Morrison D, Woodford N, Cookson B. Enterococci as emerging pathogens of humans. J Appl Microbiol. 1997;83:89-99.

13. Omar NB, Castro A, Lucas R, Abriouel H, Yousif NM, Franz CM, et al. Functional and safety aspects of enterococci isolated from different Spanish foods. Syst Appl Microbiol. 2004;27:118-30

14. Franz CM, Huch M, Abriouel H, Holzapfel W, Gálvez A. Enterococci as probiotics and their implications in food safety. Int J Food Microbiol. 2011;151:125-40.

15. Werner G, Coque T, Hammerum A, Hope R, Hryniewicz W, Johnson A, et al, Emergence and spread of vancomycin resistance among enterococci in Europe. Eurosurveillance. 2008;13:1-11.

16. Ogier JC, Serror P. Safety assessment of dairy microorganisms: The Enterococcus genus. Int J Food Microbiol. 2008;126:291-301.

17. Cocconcelli PS, Cattivelli D, Gazzola S. Gene transfer of vancomycin and tetracycline resistances among Enterococcus faecalis during cheese and sausage fermentations. Int J Food Microbiol. 2003;88:315-23.

18. Eaton TJ, Gasson MJ. Molecular screening of enterococcus virulence determinants and potential for genetic exchange between food and medical isolates. Appl Environ Microbiol. 2001;67:1628-35.

19. Touré R, Kheadr E, Lacroix C, Moroni O, Fliss I. Production of antibacterial substances by bifidobacterial isolates from infant stool active against Listeria monocytogenes. J Appl Microbiol. 2003:95:1058-69.

20. Cheikhyoussef A, Pogori N, Chen H, Tian F, Chen W, Tang J, et al. Antimicrobial activity and partial characterization of bacteriocin-like inhibitory substances (BLIS) produced by Bifidobacterium infantis BCRC 14602. Food Control. 2009;20:553-9.

21. Yamamoto $Y$, Togawa $Y$, Shimosaka M, Okazaki M. Purification and characterization of a novel bacteriocin produced by Enterococcus faecalis strain RJ-11. Appl Environ Microbiol. 2003;69:5746-53.

22. Favaro L, Basaglia M, Casella S, Hue I, Dousset X, Gombossy de Melo Franco $\mathrm{BD}$, et al. Bacteriocinogenic potential and safety evaluation of non-starter Enterococcus faecium strains isolated from home made white brine cheese. Food Microbiol. 2014:38:228-39.

23. Jennes W, Dicks L, Verwoerd D. Enterocin 012, a bacteriocin produced by Enterococcus gallinarum isolated from the intestinal tract of ostrich. J Appl Microbiol. 2000;88:349-57.

24. Toit MD, Franz C, Dicks L, Holzapfel W. Preliminary characterization of bacteriocins produced by Enterococcus faecium and Enterococcus faecalis isolated from pig faeces. J Appl Microbiol. 2000;88:482-94.

25. Belguesmia Y, Choiset $Y$, Prévost H, Dalgalarrondo M, Chobert JM, Drider D. Partial purification and characterization of the mode of action of enterocin S37: a bacteriocin produced by Enterococcus faecalis S37 isolated from poultry feces. J Environ Public Health. 2010;2010:1-8.

26. Amoa-Awua WK, Owusu M, Feglo P. Utilization of unfermented cassava flour for the production of an indigenous African fermented food, agbelima. World J Microbiol Biotechnol. 2005;21:1201-7.
27. Mante ES, Sakyi-Dawson E, Amoa-Awua WK. Antimicrobial interactions of microbial species involved in the fermentation of cassava dough into agbelima with particular reference to the inhibitory effect of lactic acid bacteria on enteric pathogens. Int J Food Microbiol. 2003;89:41-50.

28. Anyogu A, Awamaria B, Sutherland J, Ouoba L. Molecular characterisation and antimicrobial activity of bacteria associated with submerged lactic acid cassava fermentation. Food Control. 2014;39:119-27.

29. Bhavnani SM, Drake JA, Forrest A, Deinhart JA, Jones RN, Biedenbach DJ, et al. A nationwide, multicenter, case-control study comparing risk factors, treatment, and outcome for vancomycin-resistant and-susceptible enterococcal bacteremia. Diagn Microbiol Infec Dis. 2000;36:145-58.

30. Messi P, Guerrieri E, De Niederhaeusern S, Sabia C, Bondi M. Vancomycin-Resistant Enterococci (VRE) in meat and environmental samples. Int J Food Microbiol. 2006;107:218-22.

31. Hadji-Sfaxi I, El-Ghaish S, Ahmadova A, Batdorj B, Le Blay-Laliberté G, Barbier $\mathrm{G}$, et al. Antimicrobial activity and safety of use of Enterococcus faecium PC4. 1 isolated from Mongol yogurt. Food Control. 2011;22:2020-7.

32. Cetinkaya Y, Falk P, Mayhall CG. Vancomycin-resistant enterococci. Clin Microbiol Rev. 2000;13:686-707

33. Huycke MM, Sahm DF, Gilmore MS. Multiple-drug resistant enterococci: the nature of the problem and an agenda for the future. Emerg Infect Dis. 1998:4:239-49.

34. Arias CA, Murray BE. The rise of the enterococcus: beyond vancomycin resistance. Nat Rev Microbiol. 2012;10:266-78.

35. López M, Sáenz Y, Rojo-Bezares B, Martínez S, del Campo R, Ruiz-Larrea F, et al. Detection of vanA and vanB2-containing enterococci from food samples in Spain, including Enterococcus faecium strains of CC17 and the new singleton ST425. Int J Food Microbiol. 2009;133:172-8.

36. Nallapareddy SR, Singh KV, Okhuysen PC, Murray BE. A functional collagen adhesin gene, acm, in clinical isolates of Enterococcus faecium correlates with the recent success of this emerging nosocomial pathogen. Infect Immun. 2008;76:4110-9.

37. Vankerckhoven V, Van Autgaerden T, Vael C, Lammens C, Chapelle S, Ross $R$, et al. Development of a multiplex PCR for the detection of asar, gelE, $c y \mid A$, esp, and hyl genes in enterococci and survey for virulence determinants among European hospital isolates of Enterococcus faecium. J Clin Microbiol. 2004;42:4473-9.

\section{Submit your next manuscript to BioMed Central and take full advantage of:}

- Convenient online submission

- Thorough peer review

- No space constraints or color figure charges

- Immediate publication on acceptance

- Inclusion in PubMed, CAS, Scopus and Google Scholar

- Research which is freely available for redistribution

Submit your manuscript at www.biomedcentral.com/submit 